\title{
YMPÄRISTÖ JA EETTINEN KASVATUS
}

\begin{abstract}
Ympäristöetiikka on muovannut etiikan kosketuspintaa yhä laajemmaksi: ulottumaan paitsi ihmisen ja yhteiskunnan välisiin suhteisiin, myös luontoon, eläimiin ja tuleviin sukupolviin. Kristillinen Opintokeskus on ollut vuosien ajan aktiivinen ympäristökasvattaja. Muistamme mm. 1980-luvun loppupuolelta jokakodin ympäristöystävällisen kuluttajaoppaan Sanoista tekoihin. Uusin projekti käsittelee ympäristöetiikkaa ja on nimeltään Etiikka, hyvää elämää etsimässä.
\end{abstract}

Lattialle on piirretty nelikenttä, pystyakselina on ympäristöarvojen arvostaminen. Toinen ääripää tarkoittaa, että ne ovat tärkeitä, toinen ääripää, että niillä ei ole omassa elämässä merkitystä. Toisena akselina on toimintakysymys: paljonko otan ympäristönäkökulmia huomioon ratkaisuissani ja valinnoissani. Toisessa ääripäässä ne ohjaavat valintojani, toisessa eivät lainkaan. Pyydän osallistujia valitsemaan paikkansa ruudukosta.

On tavallista, että suuri osa osallistujista valitsee kohdan, joka kertoo, että ympäristöarvot ovat tärkeitä, mutta että ne vaikuttavat omiin valintoihin vain kohtuullisesti tai vähän. Osallistujien ilmeet ja kommentit viestivät usein lievää noloutta ja hämmennystä, kun on näytettävä itselleen ja muille, että ihanteet ja arki eivät kulje käsikädessä.

jälkikeskustelussa pohditaan syitä, täsmennetään mitä kukin tarkoittaa - ja yleensä tarkoitetaan ympäristöarvoilla tai niiden kohtuullisella huomioonottamisella, mitä tunteita ja ajatuksia oma paikka herätti, mitä ristiriitoja tämän kysymyksen äärellä on, mitä perusteluja milläkin näkökannalla on, mitä pitäisi tehdä toisin -vai pitäisikö?

Ympäristönsuojelu on monisyinen eettinen kysymys ja ympäristöongelmat monitieteisiä ja moniulotteisia. (Aiheesta tarkemmin esimerkiksi Leena Vilkka, Ympäristöetiikka. Yliopistopaino 1993.)

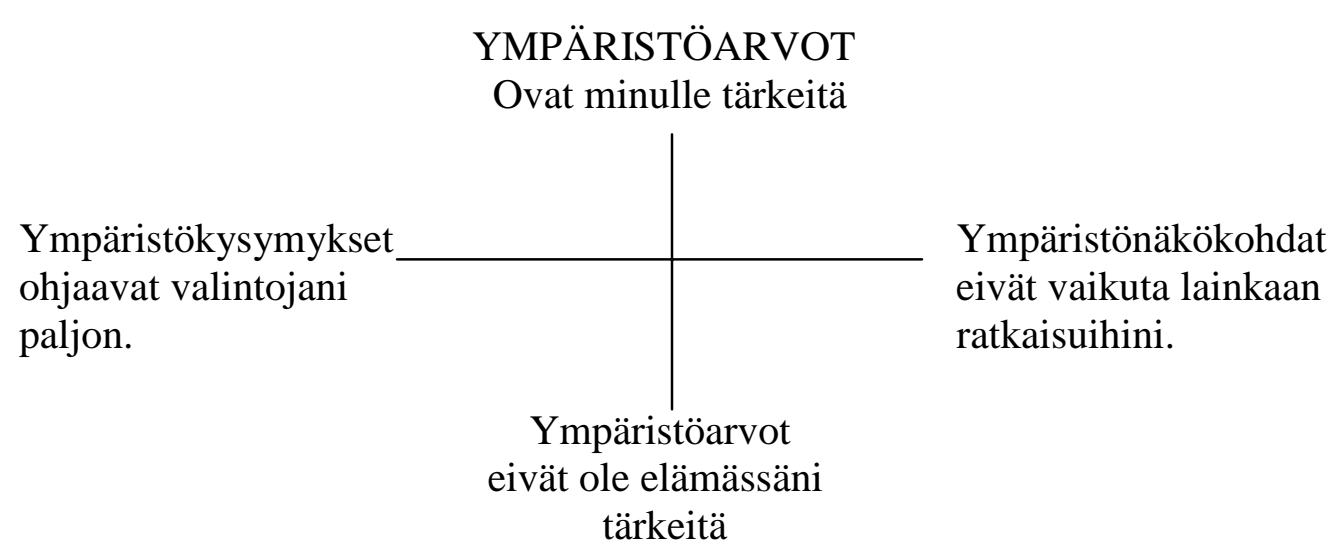


Ympäristöetiikka on muovannut etiikan kosketuspintaa yhä laajemmaksi: ulottumaan paitsi ihmisten ja yhteiskunnan välisiin suhteisiin, myös luontoon, eläimiin ja tuleviin sukupolviin. Ympäristökysymykset ovat osa sosiaalietiikkaa, yksilön oikeudet ja velvollisuudet osa ympäristöetiikkaa. Kestävien ratkaisujen tekemiseen tarvitaan yhä kokonaisvaltaisempaa näkökulmaa.

Ympäristönsuojelua voidaan tarkastella joko bio- tai antroposentrisestä näkökulmasta. Luontokeskeisesti voidaan ajatella, että luonnolla on itseisarvoinen oikeus olla olemassa ja säilyä monimuotoisena. Ihmiskeskeisesti ajateltuna kyse on ihmiskunnan tulevaisuudesta - halusta säilyttää puhdas ja elinkelpoinen luonto niin itselle kuin lapsillekin iloksi ja hyödyksi. Kyse on pitkälti sukupolvien välisestä jako-oikeudenmukaisuudesta: kuinka jaetaan luonnonvarat tai elintason nostamisesta aiheutuneet kustannukset.

\section{Ympäristöeettisiä kysymyksiä}

Ympäristöetiikka sisältää monentyyppisiä periaatteellisia kysymyksiä, joista muutama esimerkki:

- Mikä on ihmisen ja luonnon suhde - eri aatemaailmoissa, omassa maailmankatsomuksessani? Onko luonnolla itseisarvo vai välinearvo -millä perusteilla ihminen saa sen määritellä? Mikä on se luonto, jota suojellaan? Onko eläimillä oikeuksia?

- Eroaako moraali tulevia sukupolvia kohtaan muusta moraalista? jos meillä on velvollisuuksia maantieteellisesti kaukana olevia kohtaan, onko niitä myös ajallisesti kaukana olevia kohtaan?

Onko meillä velvollisuus olla vahingoittamatta tulevia sukupolvia tai onko meillä velvollisuus hyödyttää heitä? Mitä vaikuttaa se, että koko tulevien sukupolvien olemassaolo ja heidän elinympäristönsä on ratkaisevasti hallussamme?

- Säästetäänkö luontoa ihmistä varten vai varjellaanko luontoa ihmisen aiheuttamalta uhalta? Onko Kolilla tai Turunlinnalla oikeus säilyä jälkipolville, onko meillä velvollisuutta säilyttää niitä? Onko ihmisellä maahan, veteen ja ilmaan omistus- vai käyttöoikeus - vai ei kumpaakaan? - Miten arvioida ja painottaa lyhyen ja pitkän aikavälin seuraukset? Mitä valitaan, kun tehdas tuo nyt työpaikkoja, mutta pitkällä aikavälillä kuormittaa ympäristöä? Merkitseekö edullinen ydinenergia ydinjätelaskun siirtämistä lapsille?

\section{Etiikan kurssi ei anna vastauksia, vaan kysyy}

Alun nelikenttäesimerkki on yksi niistä työskentelyistä, joita Kristillisen opintokeskuksen Etiikka. Hyvää elämää etsimässä -projektin puitteissa on toteutettu. Kyseessä on aikuisille suunnattu etiikan opinto-ohjelma, jonka tarkoituksena on antaa eväitä eettisten kysymysten pohtimiseen etiikan perusteorioiden ja yhteisen prosessoinnin avulla.

Ryhmä opettelee aluksi yhteistä kieltä ja erilaisia teoreettisia työkaluja ja pureutuu sitten niiden avulla loput kokoontumiskerrat itse valitsemiinsa erityiskysymyksiin. Kurssimateriaalina on artikkelikirja Etiikka. Hyvää elämää etsimässä (toim. Heinimäki - Kanerva - Toivola), joka antaa perustiedot etiikasta ja materiaalia 16 erityiskysymyksen käsittelyyn sekä Yleisradion opetusohjelmien minikuunnelmasarja Samarialaisia. Materiaali haastaa pohtimaan, ei niinkään anna valmiita vastauksia. Ohjaajakurssilaisen palaute kiteyttää jotain olennaista: 'Aikuisetiikka on elämän epävarmuuteen suostumista."

Työskentelyssä käytetään hyväksi toiminnallisia ja eläytyviä menetelmiä. Eläytyvien menetelmien käytöllä pyritään saamaan ihokosketusta aiheeseen ja syventämään ymmärrystä eri osapuolien erilaisiin näkemyksiin - onhan selvää, ettei oppimista ja oivalluksia saada aikaan pelkällä tiedonvälityksellä. Eläytyvät menetelmät pitävät myös jalat maassa sen suhteen, että ihanteiden nimeäminen ei automaattisesti anna vielä voimaa niiden toteuttamiseen. 


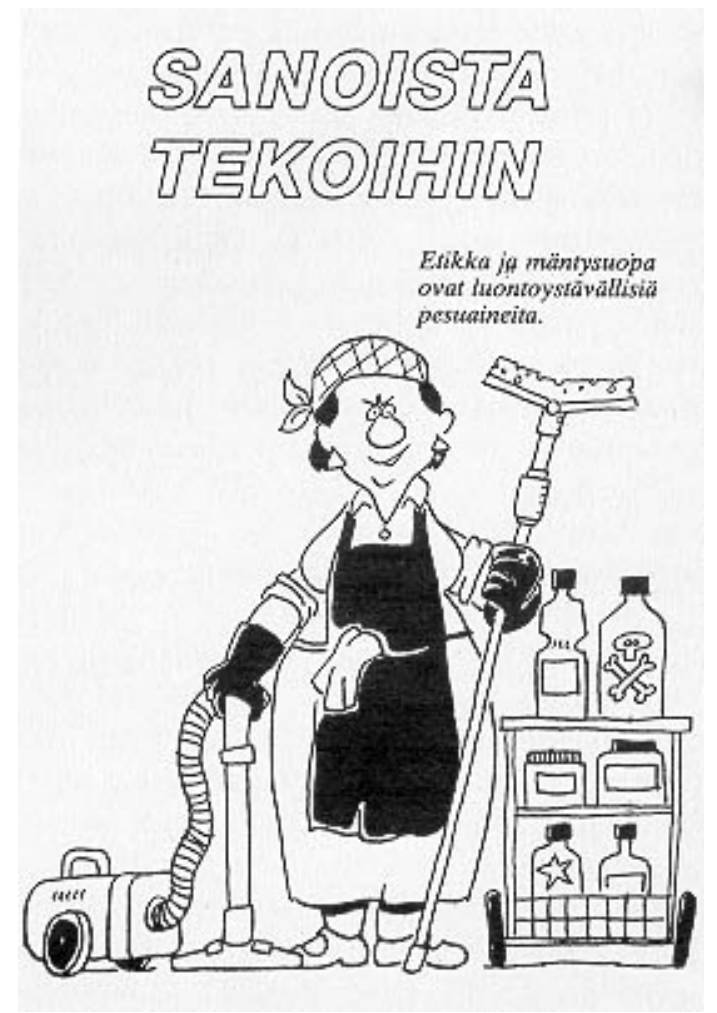

Ryhmien ohjaajille Kristillinen opintokeskus järjestää viisipäiväistä koulutusta. Kurssilla opiskellaan etiikan perustietoja, ryhmädynamiikkaa sekä monipuolisia menetelmiä eettisen pohdiskelun tueksi. Koulutettujen ohjaajien käytössä on toteuttamisideoita sisältävä ohjaajan kansio.

\section{Ympäristökasvatusta - tapauskertomus Kuhmosta}

Hyvää elämää etsimässä -kurssilla ei ole tarkoitus opiskella eettisiä teorioita pelkästään irrallisen tiedon lisäämiseksi, vaan kurssilaisilla on usein vahva motivaatio saada eväitä oman arjen oikeisiin ongelmiin. He odottavat yhteistä pohdiskelua ja monipuolisia näkökulmia, oman arvomaailman jäsentymistä ja oman toiminnan eettisten ulottuvuuksien näkemistä sekä tilaisuutta omaan ajatteluun ja oivalluksiin. Osa hakee myös uskallusta ja välineitä osallistua ajankohtaisiin keskusteluihin, kuten taitoa analysoida erilaisia argumentteja sekä arvioida eri vaihtoehtojen seurauksia (kenellä vastuu mistäkin, ketä kaikkia koskee, mitä oikeuksia, mitä velvollisuuksia, kuka jää jalkoihin).

Eräällä etiikan ohjaajakurssilla yksi tällainen konkreettinen toive oli saada valmiuksia osallistua paikkakunnalla käytävään keskusteluun ydinjätteen sijoituksesta. Teollisuuden Voima on valinnut Kuhmon yhdeksi mahdolliseksi loppusijoituspaikaksi. Paikkakuntalaisille asia on vaikea, erilaiset tärkeät asiat tuntuvat yhteensovittamattomilta. Jätehautaamo toisi työpaikkoja ja veromarkkoja köyhälle kunnalle, mutta samalla epävarmuuden turvallisuudesta ja tulevaisuudesta. Kuntalaisia painaa myös huoli kunnan hyvän maineen ja siten matkailuelinkeinon menettämisestä. Lisäksi neuvotteluihin on liittynyt epämääräistä "rahalla voitelun makua" (TVO:n sponsorirahat), mikä entisestään on herättänyt epäluuloja voimayhtiötä kohtaan. Syrjäinen kunta on kokenut joutuvansa eteläisen hyvinvointi-Suomen kaatopaikaksi.

Kurssilla asian esittelyn jälkeen ryhmä jakaantui ja eläytyi eri osapuolien edustajiksi, jotka oli kutsuttu kuultavaksi samaan tilaisuuteen. Paikalla oli TVO:n insinöörejä, kunnanjohtaja ja talouspäällikkö sekä erilaisia kuntalaisia. Ryhmä keskusteli rooleistaan käsin tuoden argumentteja sekä ydinjätteen sijoittamisen puolesta että sitä vastaan. jokainen ryhmittymä pohti myös keskenään, mikä heidän suurin huolenaiheensa tämän kysymyksen suhteen on.

Kun keskustelumateriaalia oli tarpeeksi, erilaiset argumentit kerättiin yhdessä tarkasteltaviksi ja pohdittiin, mitä arvoja niiden takana on. Esiinnousseet arvot jokainen laittoi omaan tärkeysjärjestykseensä, jonka jälkeen tuloksia ja mahdollisia johtopäätöksiä käsiteltiin yhdessä.

Luonnon ja ihmisten varjeleminen osoittautui keskeiseksi arvoksi, enimmäkseen antroposentrisesti perusteltuna. Mutta sitäkin polttavammaksi tuli tässä tapauksessa kysymys hyvästä politiikasta. Suurin ongelma oli nimittäin lopulta asioiden hoidon avoimuus ja rehellisyys - tai lähinnä niiden puute. Kyläläiset kyllä ymmärsivät, että jos on ydinvoimaloita, myös jätteet on jonnekin sijoitettava. Se mikä loukkasi ja aiheutti eniten ristiriitoja, oli tunne, että tulee kohdelluksi kuin 
lapsi, joka lahjomalla ja juksaamalla saadaan narrattua mukaan. Moni kaipasi avointa tiedottamista myös riskien osalta ja sitä, että eri osapuolet hyväksyttäisiin mukaan vakavasti otettavina keskustelukumppaneina. Silloin asukkaat voisivat myös kohdata kysymyksen aikuisina, yhdessä miettiä vaihtoehtoja ja sitoutua tehtävään ratkaisuun. Painava johtopäätös oli: mitä jos vaihteeksi kokeiltaisiin totuutta? 